\title{
Comparison of efficacy combination of inhaled phormoterol / budesonide turbuhaler vs. combination of nebulized salbutamol / ipratropium bromide on moderate asthma acute exacerbation in Persahabatan Hospital
}

\author{
Zulkarnain Barasila , Faisal Yunus ${ }^{*}$, Wiwien H. Wiyono*, Soerjanto ${ }^{f}$
}

\begin{abstract}
Abstrak
Tujuan penelitian ini untuk membandingkan efikasi kombinasi phormoterol/budesonid turbuhaler dengan kombinasi nebulisasi salbutamol/ipratropium bromid. Pengobatan utama asma akut adalah inhalasi agonis $\beta_{2}$ kerja singkat. Pasien asma saat ini menggunakan 2 obat, untuk pelega dan pengontrol. Saat ini sudah ada inhaler berisi kombinasi agonis- $\beta_{2}$ kerja lama onset cepat dan kortikosteroid. Kombinasi ini bisa digunakan untuk pengontrol dan pelega. Uji klinis acak terbuka dilakukan pada 76 pasien berusia antara 12 - 60 tahun yang datang ke RS Persahabatan dengan skor asma 8 - 12. Pasien tersebut dibagi menjadi 2 kelompok masingmasing 38 pasien. Kelompok pertama mendapat kombinasi formoterol/budesonid 4,5/160 $\mu \mathrm{g}$ turbuhaler (kelompok T), kelompok kedua mendapat kombinasi nebulisasi salbutamol/ipratropium bromid 2,5/0,25 mg (kelompok N). Setiap kelompok mendapat inhalasi tiap 20 menit, total 3 kali pemberian. Tidak ada perbedaan bermakna pada jenis kelamin, tinggi dan berat badan, APE awal dan skor asma awal antar kedua kelompok. Tampak peningkatan APE dan penurunan skor asma yang bermakna pada tiap kelompok, namun perubahan ini tidak berbeda bermakna antar kedua kelompok pada tiap interval waktu yang diamati. Efek samping, nyeri tenggorok, tremor, berdebar, terjadi pada kedua kelompok namun hanya ringan. Satu pasien pada kelompok T mengalami 3 efek samping sekaligus, 5 lainnya hanya tremor. Enam orang pada kelompok $N$ hanya mengalami tremor. Kombinasi formoterol/budesonid turbuhaler dan kombinasi salbutamol/ipratropium bromid nebulisasi secara klinis tidak berbeda bermakna dalam mengobati asma akut sedang, namun kombinasi salbutamol/ipratropium bromid nebulisasi memiliki efek samping lebih ringan. (Med J Indones 2006; 15:34-42)
\end{abstract}

\begin{abstract}
The aim of this study was to compare efficacy combination of phormoterol/budesonide turbuhaler vs. salbutamol/ipratropium bromide nebulization. Main therapy for acute asthma is inhaled short acting $\beta_{2}$-agonist. Asthma patients are using two drugs, controller and reliever. Recently there is device-containing combination of long-acting $\beta_{2}$-agonist with rapid onset and corticosteroid. This combination can act as reliever and controller. An opened randomized clinical trial of 76 patients between the ages of 12 and 60 years presenting to Persahabatan Hospital with asthma score between 8-12 participated in this study. After initial evaluation, patients were divided into two groups. Thirty-eight patients were administered combination of formoterol/budesonide $4.5 / 160 \mu \mathrm{g}$ via turbuhaler (Tgroup) every 20 minutes, total of three doses, and another 38 of salbutamol/ipratropium bromide 2.5/0.25 mg via nebulizer ( $N$-group) also with the same manner. There were no statistical difference in sex, mean age, high, weight, initial PEFR, and asthma score between two groups. The significant increased of PEFR and decreased of asthma score were observed in both groups. However, there were no significant difference of PEFR and asthma score between the two groups within every time-interval. Adverse events were mild including hoarseness, tremor and palpitation. Of T-group, 1 subject was suffered from 3 adverse events simultaneously (hoarseness, tremor and palpitation), 5 subjects were only tremor. Of $N$-group, all 6 subjects were only suffered from tremor. A combination of formoterol/budesonide turbuhaler and a combination of nebulized salbutamol/ipratropium bromide are clinically equivalent for treatment moderate acute asthma. However, nebulized salbutamol/ipratropium bromide had less adverse effects. (Med J Indones 2006; 15:34-42)
\end{abstract}

Keywords: phormoterol, budesonide, salbutamol, ipratropium bromide, acute asthma

Recommended treatments of acute asthma attack recently are $\beta_{2}$-agonist bronchodilator inhalation and

\footnotetext{
* Department of Pulmonology and Respiratory Medicine, Faculty of Medicine, University of Indonesia, Jakarta, Indonesia

${ }^{f}$ Faculty of Public Health, University of Indonesia, Depok, Indonesia
}

glucocorticoid systemic for patients, which do not response to bronchodilator only. ${ }^{1}$ Adding systemic corticosteroid in acute asthma attack has been proven to decrease number of in-patient, significantly decrease incidence of acute asthma exacerbation, and increase lung function after exacerbation compared to bronchodilator only. ${ }^{1,2}$ It is said that long-term systemic 
corticosteroid is safe, but has potential of side effects, especially for patients with recurring attacks. Systemic corticosteroid intravenously on the other hand does not always easy to be administered. ${ }^{3}$

The goals of asthma management do not only prevent and treat asthma exacerbation but also chronic asthma. Phormoterol fumarate dihydrate is a long acting $\beta_{2}$-agonist with rapid onset. The roles of $\beta_{2}$-agonist are increasing both for acute and chronic/stable asthma. The development of devices for delivering asthma drugs such as metered dose inhaler (MDI), MDI + with spacer, rotahaler, autohaler, turbuhaler, diskhaler, or easyhaler are more popular in recent year. Inhalation devices can produce small dose, minimum systemic side effects, and place the drug right on target cells or location of inflamation. ${ }^{4}$

Budesonide is a glucocorticoid, which developed for topical anti-inflamation, (e.g. asthma and rhinitis). Inhalation corticosteroid has high topical-systemic ratio effect and shows very good result in controlling asthma. This is explained by a combination of a relatively high local anti-inflamatory effect, extensive first pass hepatic degradation of orally absorbed drug (85-90\%) and low potency of metabolites. ${ }^{5}$

In the previous study budesonide/phormoterol combination showed ability as reliever which can release airway obstruction in 4 minutes. ${ }^{6}$ Gibson et al. ${ }^{7}$ stated that after 6 hours of budesonide inhalation, there was significant changes in airway reactivity, $12 \%$ eosinophile degradation, and $4 \%$ increasing of force expiration volume in 1 second (FEV1). Beside anti-inflamatory feature, corticosteroid has also $\beta_{2}$ mimetic action which work 2-4 hours after delivery and increased $\beta_{2}$ receptor regulation. Inhaled corticosteroid has high poten of topical effect with minimal systemic effect, and has shown very good results in controlling asthma in children and adults. ${ }^{4}$

\section{METHODS}

This was an open randomized clinical trial on 76 moderate acute asthma patients, which came to emergency unit or asthma clinic in Persahabatan Hospital. This trial has been proved by ethical committee of University of Indonesia Medical Faculty. We started this study on April 2005 until July 2005. Seventy-six subjects enrolled this study until completed.

The inclusion criteria were moderate acute asthma, male or female of 12-60 years old with asthma score
8-12 as seen in table 1 , subject could perform peak expiratory flow maneuver, and gave written agreement to enroll this study.

The patients were given information about the aim of this study, agreed to enroll until completed, stated orally and sign informed consent paper. Moderate asthma acute patients, which met with inclusion criteria and agreed to enroll this study, were divided randomly into 2 groups. We gave dry-powder inhalation of phormoterol/budesonide combination to the treatment group with doses of 4.5/160 $\mu$ g (T-group). Repeated inhalation were administered at 20 and 40 minutes. Control group was given nebulized of $2.5 / 0.5 \mathrm{mg}$ salbutamol/ipratropium bromide combination ( $\mathrm{N}$-group). Nebulization was administered with jet nebulizer (merk DeVILBISS). Repeated inhalation were performed at 20 and 40 minutes. We did physical examination and wrote all data collected.

Evaluations were performed on breathless, talking, allertness, respiratory rate, heart rate, respiratory muscle retraction, wheeze, and peak expiratory flow rate (PEFR). Peak expiratory flow rate was measured with peak flow meter mini Wright (Airmed, Clement Clarke International Ltd. London. England). The highest value was taken among three times measurements with difference among values not more than $5 \%$. Those values were then compared to normal PEFR predicted values of Indonesian people from Pneumobil Indonesia Project. ${ }^{9}$ Peak expiratory flow rates were measured at first time visit before initial therapy then at 5, 7, 10, 15, $3060,120,180,240,300$, and 360 minutes. These result then were scored according to table 1 .

We used asthma-scoring table to evaluate improvement of the attack. Score were noted before initial treatment then $20,40,60,120,180,240,300,360$ minutes. Side effects, which would be expected, were tremor, palpitation, hoarseness, soar throat, and tachycardia. If there were side effects, we scored 1 and 0 if there were not. If there were fever, or color changing sputum, or leucosite $>10.000 / \mathrm{m}^{3}$, or there were infiltrates in chest $\mathrm{x}$-ray, then patients were given antibiotics and excluded from trial. Oxygen 3-4 L/min was administered. At the end of trial patients with incomplete response and asthma-scoring $>4$, would be treated in the emergency unit. These patients continued enrolling the study and their data would be evaluated and tested. Total cost was counted based on the cost in Persahabatan Hospital. 
Table 1. Score of asthma attack*

\begin{tabular}{|c|c|c|c|c|c|}
\hline Parameter & Normal & Mild & Moderate & Severe & Life threat \\
\hline Breathless & $\begin{array}{l}\text { No } \\
(0)\end{array}$ & $\begin{array}{l}\text { Walking } \\
\text { (1) }\end{array}$ & $\begin{array}{l}\text { Talking } \\
\text { (2) }\end{array}$ & $\begin{array}{l}\text { At rest } \\
\text { (3) }\end{array}$ & \\
\hline Talking & $\begin{array}{l}\text { Normal } \\
(0)\end{array}$ & $\begin{array}{l}1 \text { sentence } \\
\text { (1) }\end{array}$ & $\begin{array}{l}\text { Phrases } \\
\text { (2) }\end{array}$ & $\begin{array}{l}\text { Words } \\
(3)\end{array}$ & \\
\hline Alertness & $\begin{array}{l}\text { Normal } \\
(0)\end{array}$ & $\begin{array}{l}\text { Maybe agitated } \\
(0)\end{array}$ & $\begin{array}{l}\text { Usually agitated } \\
\text { (1) }\end{array}$ & $\begin{array}{l}\text { Agitated } \\
(2)\end{array}$ & $\begin{array}{l}\text { Decrease } \\
\text { (3) }\end{array}$ \\
\hline Respiratory rate & $\begin{array}{l}12-20 \\
(0)\end{array}$ & $\begin{array}{l}<30 \\
(1)\end{array}$ & $\begin{array}{l}<30 \\
(2)\end{array}$ & $\begin{array}{l}>30 \\
(3)\end{array}$ & \\
\hline $\begin{array}{l}\text { Respiratory } \\
\text { retraction }\end{array}$ & No & No & Usually & Usually & $\begin{array}{l}\text { Paradoxical thoraco- } \\
\text { abdominal movement }\end{array}$ \\
\hline Wheeze & No & $\begin{array}{l}\text { Moderate, often } \\
\text { only end expiratory }\end{array}$ & Loud & Louder & Absence of wheeze \\
\hline & $(0)$ & (1) & (2) & (3) & (4) \\
\hline Heart rate & $\begin{array}{l}<100 \\
(0)\end{array}$ & $\begin{array}{l}<100 \\
(0)\end{array}$ & $\begin{array}{l}100-120 \\
(1)\end{array}$ & $\begin{array}{l}>120 \\
(2)\end{array}$ & $\begin{array}{l}\text { Bradycardia } \\
\text { (3) }\end{array}$ \\
\hline $\begin{array}{l}\text { PEFR after initial } \\
\text { bronchodilator }\end{array}$ & $\begin{array}{l}>80 \% \\
\text { predicted }\end{array}$ & $\begin{array}{l}>80 \% \\
\text { predicted }\end{array}$ & $\begin{array}{l}60-80 \% \\
\text { predicted }\end{array}$ & $\begin{array}{l}<60 \% \\
\text { predicted or } \\
<100 \mathrm{~L} / \mathrm{min}\end{array}$ & \\
\hline & $(0)$ & $(0)$ & $(1)$ & (2) & \\
\hline Total score & $\mathbf{0}$ & 4 & 11 & 19 & \\
\hline
\end{tabular}

*: Modified from GINA ${ }^{8}$

\section{Statistical Analysis}

We used SPSS 10 to analyze the data. Parametric test was performed on interval and ratio data. Nonparametric test was performed on nominal and ordinal data. For parametric values such as PEFR L/min or PEFR\% predicted, pulse rate, respiratory rate, and asthma score, we used mean values. Sex, side effects, asthma score, stage of chronic asthma, and every score of variable asthma were categorized to nonparametric values. Independent samples-t test was used to show significant difference of two means, while chi square test was used to show significant difference of 2 proportional values. To show significant difference within group and between group we used paired samples-t and independent samples- $t$ test. A $P$ value of less than 0.05 was considered statistically significant.

\section{RESULTS}

Seventy-six subjects of moderate asthma attack were divided randomly into two groups, T-group and $\mathrm{N}$ - group, 38 in each group. All subjects enrolled trial until completed.

Distribution of sex was $29(76.3 \%)$ female and 9 $(23.7 \%)$ male subjects in T-group, while $28(73.7 \%)$ female and $10(26.3 \%)$ male subjects in $\mathrm{N}$-groups. These data was not statistically significant.

Confounding factors such as ages, highs, weights, PEFR predicted values, and initial PEFRs, were not statistically significant.

\section{Breathless}

The difference of breathless between the two groups was not statistically significant. Of $\mathrm{T}$ - group 5 (13.2\%) subjects with score 1 and $33(86.8 \%)$ subjects with score 2, while of $\mathrm{N}$ - group $6(15.8 \%)$ subjects with score 1 and $32(84.2 \%)$ subjects with score $2, P$ value $>0.05(P=1.000)$. Until the end of observation (360 minutes) there were no subjects with breathless complain, figure 1 . 


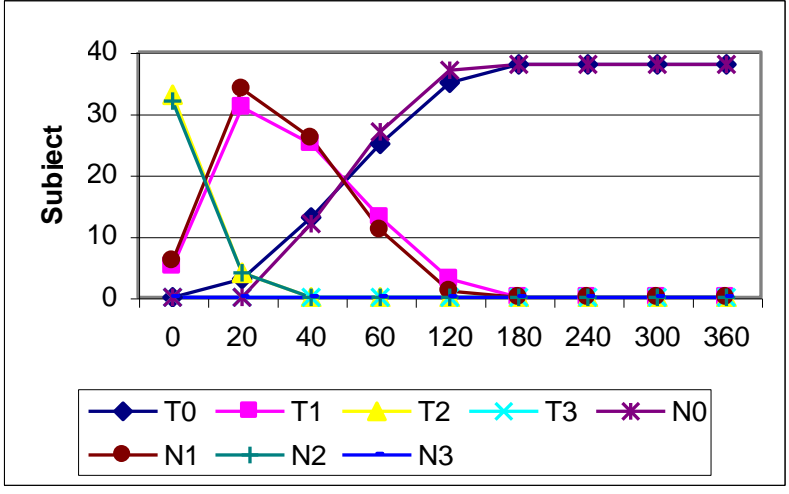

Figure 1. Changes of breathless score between two groups.

$T 0=\sum T$ subjects with score $0 ; T 1=\sum T$ subjects with score 1 ; $T 2=\sum T$ subjects with score $2 ; T 3=\sum T$ subjects with score 3 ; $N 0=\sum N$ subjects with score $0 ; N 1=\sum N$ subjects with score 1 ; $N 2=\sum N$ subjects with score $2 ; N 3=\sum N$ subjects with score 3 .

\section{Talking ability}

At initial observation, there was no significant difference of talking ability between two groups. Of T-group 9 (23.7\%) subjects with score 1 and 29 (76.3\%) subjects with score 2 , while of $\mathrm{N}$-groups $4(10.5 \%)$ subjects with score 1 and $34(89.5 \%)$ subjects with score 2 . $P$ value $>0.05(P=0.223)$. Until the end of observation (360 minutes), all subjects could talk normally, figure 2.

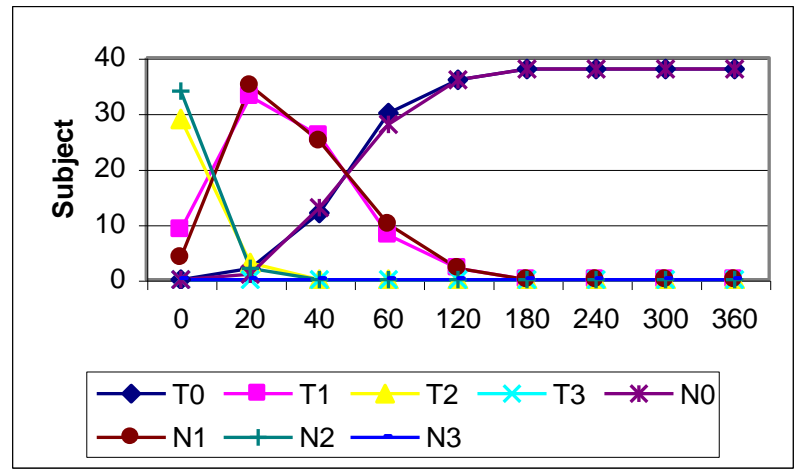

Figure 2. Changes of talking disturbance between two groups.

$T 0=\sum T$ subjects with score $0 ; T 1=\sum T$ subjects with score 1 ; $T 2=\sum T$ subjects with score $2 ; T 3=\sum T$ subjects with score 3 ; $N 0=\sum N$ subjects with score $0 ; N 1=\sum N$ subjects with score 1 ; $N 2=\sum N$ subjects with score $2 ; N 3=\sum N$ subjects with score 3 .

\section{Alertness}

All subjects in both groups were fully alert from the start until the end of observations.

\section{Respiratory rate}

A significant $(P<0.05)$ net reduction of respiratory rate was observed in both groups, but there was no significant difference between two groups. The final mean respiratory rate were normal in both groups, $17.32 \pm 1.25 \mathrm{breath} / \mathrm{min}$ in T-group and $16.95 \pm 1.21$ breath/min in N-group. All patients presented an increase in respiratory rate but no significant difference in respiratory rate score between two groups $(P>0.05$; $P=1.000)$.

Mean respiratory rate at first visit were $26.63 \pm 1.87$ breath/min in T-group and $26.47 \pm 1.77 \mathrm{breath} / \mathrm{min}$ in $\mathrm{N}$-group. There was no significant difference between two groups $(P>0.05 ; P=0.815)$, figure 3 .

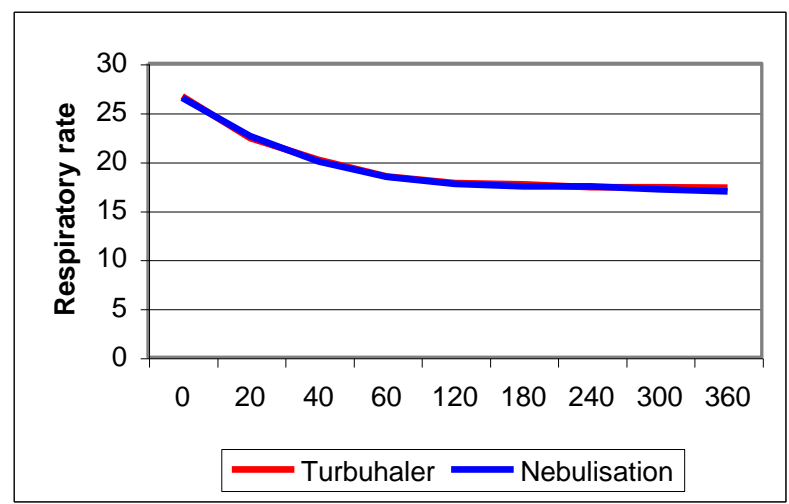

Figure 3. Changes in respiratory rate between the two groups.

To show reduction of respiratory rate in every timeinterval we found significant reduction of respiratory rate between $0-120$, then 180-240 minutes in T-group, and between $0-120$, then 240-360 minutes in N-group. Until the end of observation reduction, respiratory rate was $9.32 \pm 2.19(P<0.05 ; P=0.000)$ in T- group and was $9.53 \pm 1.99(P<0.05 ; P=0.000)$ in $\mathrm{N}$-group.

\section{Respiratory muscle retraction (accessory muscles and suprasternal retraction)}

At first time visit there was no significant difference between two groups. There were $28(73.7 \%)$ subjects with score 1 and $10(26.3 \%)$ subjects with score 2 in T-group, while in N-group there were $35(92.1 \%)$ subjects with score 1 and 3 (7.9\%) subjects with score 2 . There was no statistical difference, $P>0.05(P=$ $0.068)$. There was no respiratory muscle retraction in all subjects at the end of observation. 


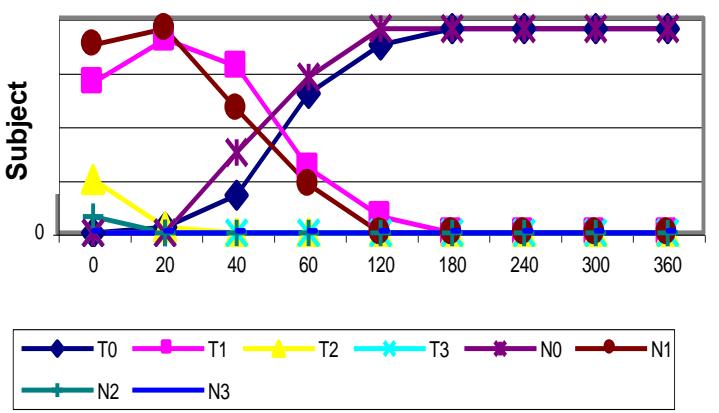

Figure 4. Changes in accessory muscle and suprasternal retraction score between the two groups.

$T 0=\sum T$ subjects with score $0 ; T 1=\sum T$ subjects with score 1 ; $T 2=\sum T$ subjects with score $2 ; T 3=\sum T$ subjects with score 3 ; $N 0=\sum N$ subjects with score $0 ; N 1=\sum N$ subjects with score 1; $N 2=\sum N$ subjects with score $2 ; N 3=\sum N$ subjects with score 3 .

\section{Wheeze}

At first time visit there was no significant difference between the two groups. There were $1(2.6 \%)$ subject with score 1 , and $37(97.4 \%)$ subjects with score 2 in T-group, while in $\mathrm{N}$-group all subjects were score 2. There was no statistical difference, $P>0.05(P=$ $1,000)$. At the end of observation, all subjects were back to normal, Figure 5.

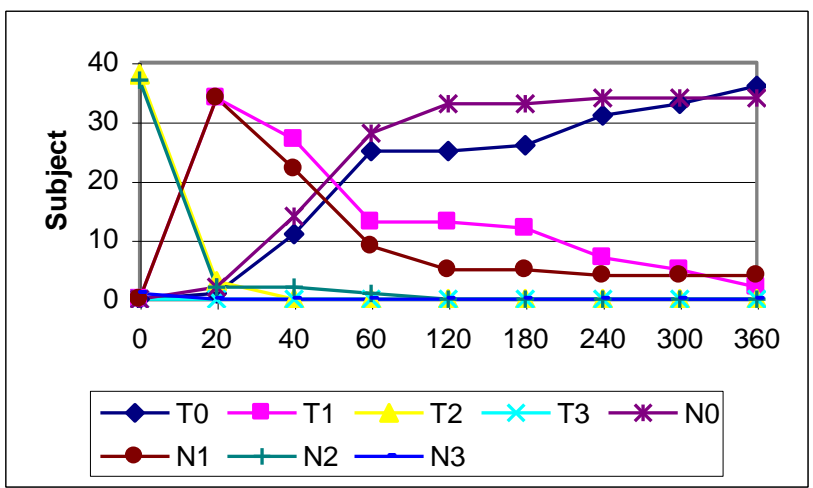

Figure 5. Changes in wheeze score between the two groups.

$T 0=\sum T$ subjects with score $0 ; T 1=\sum T$ subjects with score 1; $T 2=\sum T$ subjects with score 2; $T 3=\sum T$ subjects with score 3 ; $N 0=\sum N$ subjects with score $0 ; N 1=\sum N$ subjects with score 1 ; $N 2=\sum N$ subjects with score $2 ; N 3=\sum N$ subjects with score 3 .

\section{Heart rate}

At first time, visit heart rates were increased but there was no significant difference between two groups. A significant $(P<0.05)$ net reduction of heart rate was observed in two groups, but there was no significant difference between two groups. The final mean heart rate were normal in the two groups, $88.63 \pm 3.89$ $\mathrm{pulse} / \mathrm{min}$ in T-group and $88.66 \pm 3.21 \mathrm{breath} / \mathrm{min}$ in $\mathrm{N}$-group. All patients presented an increase in heart rate but no significant difference in heart rate score between two groups $(P>0.05 ; P=1.000)$.

Mean heart rate at first visit were $113.37 \pm 4.65$ pulse/min in T-group and $113.05 \pm 5.07 \mathrm{pulse} / \mathrm{min}$ in $\mathrm{N}$-group. There was no significant difference between two groups $(P>0.05 ; P=0.793)$ figure 6 .

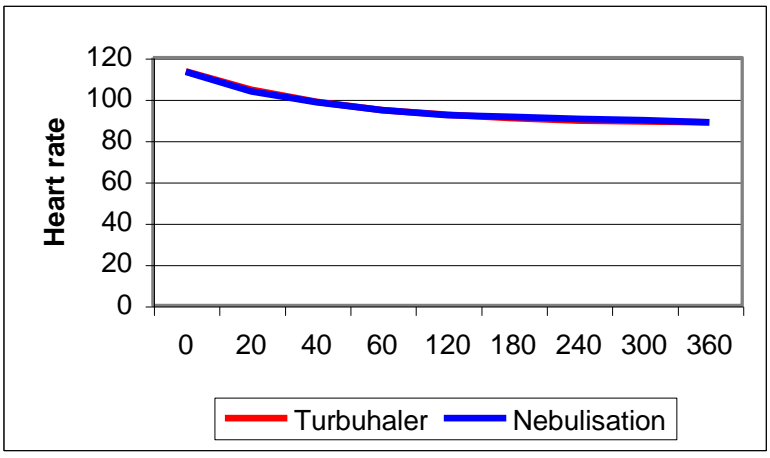

Figure 6. Changes in heart rate between the two groups.

\section{PEFR}

At first time visit there was no significant difference in PEFR score between two groups. All subjects in Tgroup were scored 2, while in N-group $2(5.3 \%)$ subjects were scored 1 and $36(94.7 \%)$ subjects were score $2(P>0.05 ; P=0.474)$. At the end of observations, in T-group there were $15(39.5 \%)$ subjects scored 0, $19(50.0 \%)$ subjects scored 1 and 4 $(10.5 \%)$ subjects scored 2. In N-group there were 19 $(50.0 \%)$ subjects scored $0,16(42.1 \%)$ subjects scored 1 and $3(7.9 \%)$ subjects scored 2 . There was no statistical difference, $P>0.05(P=0.647)$.

First mean PEFR in T-group was 150,53 \pm 45,38 $\mathrm{L} / \mathrm{min}$ and in $\mathrm{N}$-group was $169,47+35,41 \mathrm{~L} / \mathrm{min}$, there was no statistical difference $(P<0,05 ; P=$ $0,055)$ between two groups. There was variations improvement of mean PEFR in both groups. In Tgroup the improvement kept continue until 240 minutes, then there was slight reduction until the end of observation, while in $\mathrm{N}$-group improvement continued until 120 minutes, then slight reduction at 180 minutes, but rised again until the end of observation, figure 7 . 


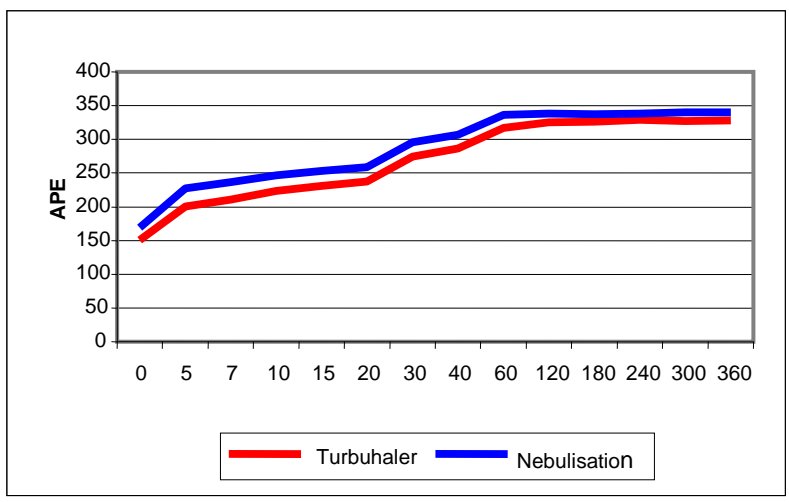

Figure 7. Changes in mean PEFR in two groups.

In T-group, we found significant improvement in every time-interval until 120 minutes, then between 180-240 minutes. There were no significant improvements in other time-intervals. In N-group, we found significant improvement in every time-interval until 60 minutes, after that there were no significant improvements until the end of observation. There was no statistical difference of PEFR improvement between two groups.

\section{Total score of asthma attack}

Mean total score of asthma attack at initial observation in $\mathrm{T}$ and $\mathrm{N}$-groups were $10.97 \pm 0.94$ and $10.79 \pm 0.78$ respectively, no statistical difference $(P>0.05 ; P=$ $0.356)$. In both group we found significant reduction of asthma attack score at 360 minutes observation. Total score reduction in $\mathrm{T}$ an $\mathrm{N}$ - groups for 360 minutes observation were $10.26 \pm 1.13(P<0.05 ; P=$ $0.000)$ and $10.21 \pm 1.04(P<0.05 ; P=0.000)$ respectively, but there was no statistical difference between two groups $(P>0.05 ; P=0.834)$.

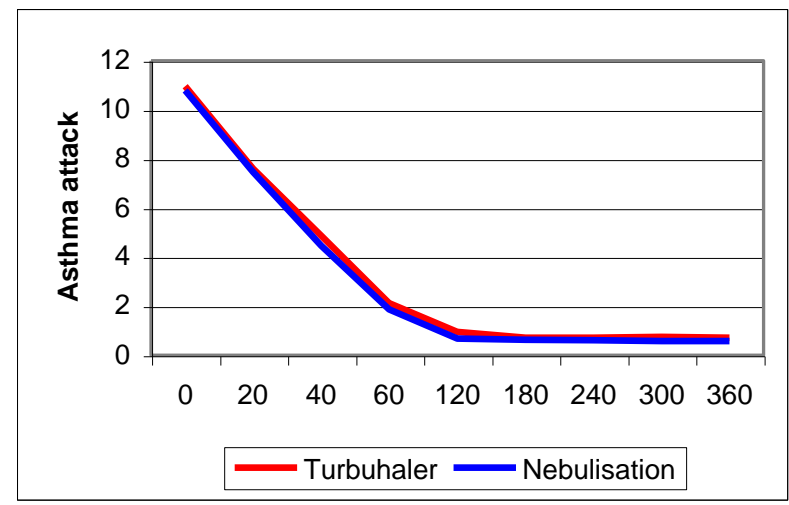

Figure 8. Changes in total score of asthma attack in both groups.

\section{Total cost}

In T-group, we calculated 3,167 Rupiahs for one time inhalation, so the total of three would be 9,501 Rupiahs. We used mouthpiece to cover turbuhaler mouthpart so this device could be used to other patients. In $\mathrm{N}$ group the cost for using nebulizer at Persahabatan Hospital was 23,000 Rupiahs for 1 time nebulization, the cost for 1 drug was 7,000 Rupiahs, so total cost would be 90,000 Rupiahs. This is ten times more expensive than T-group. Total time used for T-group was 1 hour and 20 seconds, while for $\mathrm{N}$ group was 1 hour and 45 minutes.

\section{End of Observation}

There were no subject needed for aminophyllin infusion or intravenous corticosteroid, because at 120 minutes observation the total score of asthma attack was less than 4.

We found $6(15.8 \%)$ subjects in both groups with side effects. One (2.6\%) subject in T-group had experienced of 3 side effects simultaneously, which were mild tremor, palpitation, and hoarseness. The rest 5 $(13.2 \%)$ subjects only experienced mild tremor, while in N-group all 6 subjects experienced only mild tremor.

\section{DISCUSSION}

Seventy-six patients of moderate acute exacerbation attack with total score 8-12 enrolled this study. Age, high, weight, PEFR prediction, duration of attack were not statistically difference in both groups. Female subjects were more than male subjects, 57 (75.0\%) and 19 (25.0\%) subjects respectively. This was similar with Harju et al., ${ }^{10}$ which found female patients were more often visit emergency unit because of asthma attack than male patients. Intermittent asthma was almost the same as moderate persistent asthma subjects in both groups. Sari ${ }^{11}$ found in her study that intermittent asthma were more than persistent asthma, which were suffered from severe asthma acute exacerbation.

Susanti ${ }^{12}$ in her study used scoring system with scale 0 to 4 to evaluate severity of asthma attack based on GINA 1998. Scoring system can help evaluating severity of asthma attack and improvement after treatment. This study used scoring system that had been used by Susanti ${ }^{15}$ and Sari. ${ }^{11}$ 
The difficulties in evaluating severity of asthma attack were described by previous studies. Clinical judgment cannot describe physiologic changes completely. In Our study, alertness was the only variable that not disturbed. Rudolf et al. ${ }^{13}$ evaluated arterial blood gases of 14 patients with severe asthma attack whom received a standard therapeutic regime and had similar measurements made at identical time intervals under standard conditions, and performed blood gas analysis also at identical time intervals. Hypoxemia on admission was a constant finding, and the arterial oxygen tension often took a week or longer to return to a normal level. Age, duration of the acute attack, and severity of airways obstruction were all unrelated to the changes in blood gas tension, and pulse rate was found to be a poor predictor of hypoxemia in elderly asthmatics. In this study, we did not evaluated arterial blood gases because of limited budged.

Breathless was found at all subjects on admission. Mean respiratory rates on first observation were 26.63 $\pm 1.87 \mathrm{breath} / \mathrm{min}$ in T-group and $26.47 \pm 1.77$ breath/min in $\mathrm{N}$-group, no statistical difference $(P=$ $0.706)$. Sari ${ }^{11}$ in her observation on severe asthma attack found that mean respiratory rate was 30.4 breath/min. Rodrigo ${ }^{14}$ study showed lower respiratory rate on severe asthma attack, which were 23.3 breath/min in inhalation group and $21.5 \mathrm{breath} / \mathrm{min}$ in placebo group. This study showed that respiratory rate was unrelated to severity of asthma attack.

In severe asthma attack respiratory muscle retraction and wheeze were related to severity of obstruction. ${ }^{15}$ In this study breathless, talking disturbance, increased respiratory rate, respiratory muscle retraction, wheeze, increased heart rate, and decreased PEFR were found in all subject. This is rather different with Sari ${ }^{14}$ study in severe asthma attack, which showed that not all subject were suffered from alertness deterioration.

On admission mean heart rate in T-group was 113.37 \pm 4.65 pulse/min and N-group was $113.05 \pm 5.07$ pulse/min, no statistical difference $(P=0.778)$. These values were lower than Sari ${ }^{11}$ study but higher than Rodrigo and Rodrigo ${ }^{14}$ study on severe asthma attack with PEFR predicted lower than $60 \%$.

Mean PEFR on admission, T-group was $150.53 \pm$ $45.38 \mathrm{~L} / \mathrm{min}$ and $\mathrm{N}$-group was $169.47 \pm 35.41 \mathrm{~L} / \mathrm{min}$, there was no statistical difference $(P=0.055)$. Immediate release of bronchospasm of $\mathrm{N}$-group was more superior to T-group but this was not significantly difference $(P=0.204)$.
This study showed that PEFR did not correlate with course therapy administered. Some of previous study showed same results. Other study evaluated drypowder inhaler (turbuhaler) and MDI with spacer, and showed no significant difference in pulmonary function and length of observation in emergency unit before discharged in both treatment. ${ }^{16}$

Ipratropium bromide was fourth generation of atropine, which less absorbed by airway epithelial, so there is no serious side effects if use by inhalation. Bronchodilator onset of this drug is not as fast as $\beta_{2^{-}}$ agonist but has longer duration of action. ${ }^{17}$ It has better bronchodilator effect if added to $\beta_{2}$-agonist than $\beta_{2}$-agonist alone and less doses of both drugs. Metaanalysis study of asthma attack showed that adding anticholinergic to $\beta_{2}$-agonist will increase $\mathrm{FEV}_{1} 7 \%$ $(100 \mathrm{~mL})$ and PEFR 22\% (32 mL/min). Patients who had worst airway obstruction seemed to have more advantage with this combination. ${ }^{18}$ This has yet been fully understood why patient with severe asthma attack gave better response with ipratropium bromide. Maybe patients with severe asthma attack had more sensitive response to cholinergic. Study with children showed more consistent results with this drug. ${ }^{17,18}$ There is an agreement that children have more sensitive cholinergic tone to anticholinergic than adults. ${ }^{17}$

At 5 minutes observation there were $26(68.4 \%)$ subjects in T-group who increased more than $15 \%$ PEFR, while in N-group there were $30(78.9 \%)$ subjects who increased PEFR more than $15 \%$, but there was no statistical difference $(P=0.435)$. Total subjects who had experience $15 \%$ increased PEFR were varying in every time interval in both group but there was no statistical difference. Palmqvist et al. ${ }^{6}$ compared rapid onset of brochodilator effect of formoterol/budesonide combination with salmeterol / fluticasone and placebo. All drugs were administered using dry powder inhaler. They found that combination of formoterol/budesonide showed superior bronchodilator effect than combination of salmeterol/fluticasone or placebo.

At 40 minutes observation there were 37 (97.4\%) subjects in T-group increased more than $15 \%$ PEFR, while in N-group $100 \%$ subjects did. Palmqvist et al. ${ }^{6}$ divided 2 criteria of improvement which were $15 \%$ $\mathrm{FEV}_{1}$ and $10 \% \mathrm{FEV}_{1}$. After 1 hour observation they found $75 \%$ of formoterol/budesonide group and less than $50 \%$ of salmeterol/fluticasone met the first criteria, while $90 \%$ of first group and $70 \%$ of second group met second criteria. 
Corticosteroid is effective as controller for asthma patients. It can improve lung function, symptoms, less visit to emergency unit, and duration of in-patient. However, study on how this drug role in asthma attack is still unclear. Some studies have shown steroids to offer benefit as early as 1 to 2 hours after administration, others question the efficacy of steroids even 12 hours or more after administration. ${ }^{19}$ Sari $^{11}$ studied 6 hour of nebulized fluticasone compared to intravenous methylprednisolone on severe asthma attack, concluded that there was benefit in PEFR improvement, but there was no significant difference between both groups.

Combination of salbutamol/ipratropium bromide according to GINA 2004 is a continued treatment if initial treatment only give incomplete or bad response. We used this combination as a control based on Stoodley et al. ${ }^{18}$ study which showed that this treatment had better benefit to increase PEFR than salbutamol alone. Ipratropium bromide has inferior bronchodilator effect than $\beta_{2}$-agonist, but can give additional effect if combined with $\beta_{2}$-agonist and is an alternative treatment for patients who have $\beta 2$-agonist intolerance. ${ }^{8}$

Mean PEFR and PEFR\% predicted values that reached by both group showed significant immediate response of bronchodilator effect but no significant difference between two groups. These values also showed that until the end of observation combination of formoterol / budesonide with dry powder inhaler was comparable to combination of nebulized salbutamol/ipratropium bromide on improving lung function. This rapid onset was also shown by Palmqvist et al. ${ }^{6}$ study which showed that $4.5 / 160 \mu \mathrm{g}$ formoterol/budesonide could give rapid onset in 3 minutes and doubled the doses would not give significant beneficial effect on $\mathrm{FEV}_{1}$.

Clinical improvement on both groups could be seen in mean total score at every time interval. Mean total score on admission in T-group was $10.97 \pm 0.94$ and in N-group was $10.79 \pm 0.78$, no statistical difference $(P=0.356)$. Total score reduction until end of observation were $10.26 \pm 1.13$ in T-group and $10.21 \pm$ 1.04 in $\mathrm{N}$-group, this reduction was statistically significant in each group $(P=0.000)$.

Aminophylline infusion was not needed for both groups because total score of every subject after 120 minutes was less than 4 . Weinberger ${ }^{20}$ stated that adding theophylline would not give quick benefit but after 24 hours it had benefit for severe bronchospasm. Observation on side effects, we found $6(15.8 \%)$ subjects in each groups. One (2.6\%) subject in T-group had experienced of 3 side effects which were tremor, palpitation, and hoarseness. The rest $5(13.2 \%)$ subjects only experienced mild tremor, while in $\mathrm{N}$-group all 6 subjects experienced only mild tremor. Tremor usually happens in old people, this is caused by $\beta_{2 \text { - }}$ agonist stimulation on skeleton muscles. ${ }^{21}$ Taylor et al. ${ }^{22}$ evaluated interaction of corticosteroid with $\beta_{2^{-}}$ agonist, concluded that corticosteroid did not worsen cardiovascular response. Meta-analysis study from Edmonds et al. ${ }^{23}$ showed that all treatment with corticosteroids was well tolerated, with few reports of adverse side effects, only 1 study showed mild side effect but not significant.

The cost that should be expensed in T-group was far cheaper than N-group. Total cost for three times treatment with dry powder inhaler plus mouth piece only took 9,501 Rupiahs, while for $\mathrm{N}$-group needed 90,000 Rupiahs (10 x). Also N-group took time longer than T-group. Nebulized instrument will cost about 900,000 Rupiahs, maintenance and electricity will raise the cost if patients have their own devices. Turbuhaler is more practice and easier than nebulizer.

\section{CONCLUSIONS}

1. Combination of phormoterol/budesonide in turbuhaler could give quick release of bronchospasm but there was no statistical difference with combination of nebulized salbutamol/ipratropium bromide in all parameter we measured.

2. There was no statistical difference in clinical improvement between both groups.

3. Treatment with drugs combination in turbuhaler was more practice and cheaper than nebulizer.

4. There were no statistical difference in efficacy and side effects in both groups.

\section{REFERENCES}

1. Rodrigo G, Rodrigo C. Corticosteroid in the emergency department therapy of acute adult asthma. An evidence base evaluation. Chest 1999;116:285-95.

2. McFadden ER Jr. Dosages of corticosteroid in asthma. Am Rev Respir Dis 1993;147:1306-10.

3. Jackson WF. Nebulized pulmicort therapy. A scientific and practical review. Clinical Vision Ltd and Astra Draco AB: 1998. p. 6-81.

4. Fink JB. Metered-dose inhalers, dry powder inhalers, and transitions. Respir Care 2000; 45(6):623-35.

5. Budesonide. Mosby's Drug Consult. MD Consult web site: Mosby, Inc.; 2003. 
6. Palmqvist $\mathrm{M}$, Arvidsson $\mathrm{P}$, Beckman $\mathrm{O}$, Peterson $\mathrm{S}$, Lötvall J. Onset of bronchodilation of budesonide/formoterol vs. salmeterol/fluticasone in single inhalers. Pulm Pharmacol Ther 2001; 14: 29-34.

7. Gibson PG, Saltos N, Carty K, Wilson A, Perkin K. Acute asthma effector budesonide in airway eosinophils and airway responsiveness in asthma. Am J Respir Crit Care Med 2001;163: 32-6.

8. O'Byrne P, Bateman ED, Busse W, Bousquet J, Clark T, Lenfant $\mathrm{C}$, et al. Establish individual plans to manage asthma attacks. In: Global initiative for asthma. Pocket guide for asthma management and prevention. NHBLI, WHO Revised 2004; p. 22-6.

9. Tim Pneumobile Project Indonesia. Nilai normal faal paru Indonesia. 1992.

10. Harju T, Keistinen T, Tuuponen T, Kivela S. Hospital admissions of asthmatics by age and sex. Allergy 1996;51: 693-6.

11. Sari A, Yunus F, Wiyono WH, Jusuf A, Hupudio H. Efikasi flutikason propionat nebulisasi pada serangan asma akut berat dibandingkan dengan metilprednisolon intra-vena (masa pengamatan 6 jam). Maj Kedokt Indon 2005;55:463-71.

12. Susanti F, Yunus F, Giriputro S, Manunnegoro H, Jusuf A, Bachtiar A. Efikasi steroid nebulisasi dibandingkan steroid intravena pada penatalaksanaan asma akut berat. Maj Kedokt Indon 2002;52;247-54.

13. Pearson MG, Sperce DP, Ryland I, Harrison BDW. Value of pulsus paradoxus in assess-ing acute severe asthma. British Thoracic Society Standards of Care Committee. BMJ 1993;307: 659.
14. Rudolf M, Riordan JF, Grant BJ, Maberly DJ, Saunders KB. Arterial blood gas ten-sions in acute severe asthma. Eur J Clin Invest 1980;10: 55-62.

15. Rodrigo G, Rodrigo C. Inhaled flunisolide for acute severe asthma. Am J Respir Crit Care Med 1998;157: 698-703.

16. Raimondi AC, Schottlender J, Lombardi D, Molfino NA. Treatment of acute severe asthma with inhaled albuterol delivered via jet nebulizer, metered dose inhaler with spacer, or dry powder. Chest 1997;97:24-8.

17. Silverman R. Treatment of acute asthma: a new look at the old and at the new. Clin Chest Med 2000;2:361-79.

18. Stoodley RG, Aaron SD, Dales RE. The role of ipratropium bromide in the emergency management of acute asthma execerbation. A meta-analysis of randomized clinical trials. Ann Emerg Med 1999;34:8-18.

19. Edmonds ML, Camargo CA, Pollacks CV, Rowe BH. The effectiveness of inhaled cor-ticosteroids in the emergency department treatment of acute asthma: A meta-analysis. Ann Emerg Med 2002;40:145-54.

20. Silverman R. Treatment of acute asthma: a new look at the old and at the new. Clin in Chest Med 2000;2:361-79.

21. Weinberger M. The value of theophylline for asthma guest editorial. Ann Allergy 1989;122:289.

22. Braman SS. Asthma in the elderly. Clin Geriatr Med 2003;19:57-75.

23. Taylor DR, Wilkins GT, Herbisan GP, Flannery EM. Interaction between cortico-steroid and $\beta_{2}$ agonist drugs. Biochemical and cardiovascular effects in normal subjects. Chest 1992;102:519-24. 